Rapid Communication

\title{
Cryptotephra from the 74 ka BP Toba super-eruption in the Billa Surgam caves, southern India
}

\author{
Christine Lane ${ }^{\mathrm{a}, *}$, Michael Haslam ${ }^{\mathrm{a}}$, Michael Petraglia ${ }^{\mathrm{a}}$, Peter Ditchfield ${ }^{\mathrm{a}}$, Victoria Smith ${ }^{\mathrm{a}}$, \\ Ravi Korisettar ${ }^{b}$ \\ ${ }^{a}$ Research Laboratory for Archaeology and the History of Art, University of Oxford, South Parks Road, Oxford OX1 3QY, United Kingdom \\ ${ }^{\mathrm{b}}$ Department of History and Archaeology, Karnatak University, Dharwad 580003, India
}

\section{A R T I C L E I N F O}

\section{Article history:}

Received 16 March 2011

Received in revised form

5 May 2011

Accepted 11 May 2011

Available online 8 June 2011

\section{Keywords:}

Tephrochronology

Youngest Toba Tuff

Pleistocene archaeology

Indian Middle Palaeolithic

Caves

\begin{abstract}
A B S T R A C T
The $\sim 74$ ka BP Youngest Toba Tuff (YTT), from the largest known Quaternary volcanic eruption, has been found for the first time as a non-visible (crypto-) tephra layer within the Billa Surgam caves, southern India. The occurrence of the YTT layer in Charnel House Cave provides the first calendrical age estimate for this much debated Pleistocene faunal sequence and demonstrates the first successful application of cryptotephrochronology within a cave sequence. The YTT layer lies $\sim 50 \mathrm{~cm}$ below a major sedimentological change, which is related to global cooling around the MIS 5 to MIS 4 transition. Using this isochronous event layer the Billa Surgam Cave record can be directly correlated with other archaeological sites in peninsular India and palaeoenvironmental archives across southern Asia.
\end{abstract}

(c) 2011 Elsevier Ltd. All rights reserved.

\section{Introduction}

The Youngest Toba Tuff (YTT) was erupted from Sumatra, Indonesia, around 74 ka BP (Ninkovich et al., 1978). This volcanic eruption is the largest known in the Quaternary, erupting more than $2800 \mathrm{~km}^{3}$ of magma (Rose and Chesner, 1987) and dispersing visible deposits of ash from sites as far west as the Arabian Sea and reaching east to the South China Sea (Buhring et al., 2000; Oppenheimer, 2002; Schulz et al., 2002). Although the YTT eruption is not believed to have contributed to glaciation (Robock et al., 2009; Timmreck et al., 2010), the eruption took place close to the onset of global cooling associated with the end of marine isotope stage (MIS) 5 and the start of glacial MIS 4, a time when human populations were expanding out of Africa and adapting to new environments. Despite much debate over the direct impact of this super-eruption on human populations and the changing global environments (e.g. Rampino and Self, 1992; Ambrose, 1998; Petraglia et al., 2007; Williams et al., 2009, 2010; Haslam and Petraglia, 2010), the YTT undoubtedly acts as a useful isochronous horizon for the climatic transition from MIS 5 to MIS 4, and facilitates correlation of widespread sites.

Cryptotephra investigations have been used widely across Europe as a means of locating widespread tephra isochrones in

\footnotetext{
* Corresponding author. Tel.: +44 (0)1865 285203; fax: +44 (0)1865 285220.

E-mail address: christine.lane@rlaha.ox.ac.uk (C. Lane).
}

sites where they are not preserved as visible horizons (Dugmore et al., 1995; Lowe and Turney, 1997). These methods, which extract volcanic glass shards from their host sediment, have allowed known tephra fallout areas of volcanic eruptions to be greatly extended, facilitating chronostratigraphic correlations of widespread palaeoenvironmental records (e.g. Wastegård et al., 2000; Turney et al., 2004; Margari et al., 2007; Lane et al., in press). As well as tracing tephra deposits into ever more distal sites, cryptotephra investigations are also capable of locating tephra layers within sedimentary contexts where they are less concentrated and therefore do not form visible horizons. The method is therefore well suited to the study of Palaeolithic cave sediments within known tephra fallout areas, however, to date no such successful study has been published.

Here, we present the results of a cryptotephra investigation in one of the Billa Surgam caves, southern India (Fig. 1). This is the first example of a successful cryptotephra investigation within an archaeological cave record, and also within South Asia, and it demonstrates the potential extension of this dating method both across wider geographical areas and into non-open-air sedimentary deposits.

\section{The Billa Surgam caves}

The Billa Surgam caves (N 15 $26.126^{\prime}$; E $78^{\circ} 11.131^{\prime}$ ) of Andhra Pradesh have been investigated by archaeologists and 

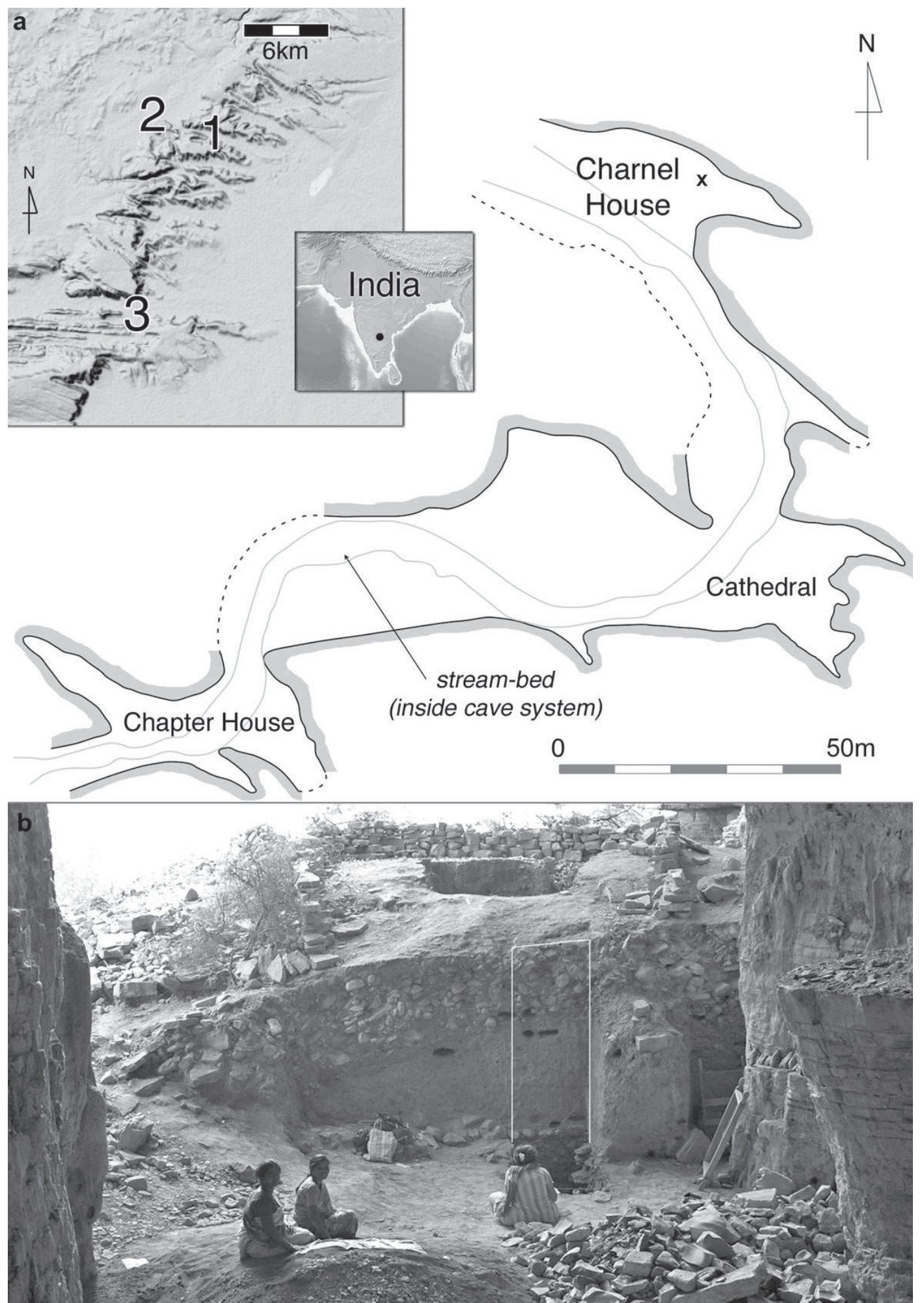

Fig. 1. (a) Map of the Billa Surgam Cave system showing the position of Charnel House Cave at its northern end; ' $x$ ' marks the spot from which the samples analysed in this study were collected. The inset shaded relief maps show the cave's location in southern India, with nearby towns marked: 1) Billa Surgam, 2) Betamcherla, 3) Jwalapuram. (b) View of the cave during excavation in 2009, facing west towards the entrance. The sampled section is outlined in white, and continues below the current cave floor level. 
environmental scientists since the mid-nineteenth century (see Haslam et al., 2010b). Excavated extensively in the 1880s at the personal request of Thomas Henry Huxley (Duff, 1883a,b 1884), this series of deep sedimentary traps extending off a winding limestone dissolution channel has played a central role in debates over southern India's Palaeolithic and faunal sequences (Newbold, 1844; Foote, 1884a,b 1885; Cammiade, 1927; Murty, 1974; Murty and Reddy, 1975; Reddy, 1977; Prasad, 1996). However, at present no absolute dates for Pleistocene deposits have been reported for any of the Billa Surgam caves, though radiocarbon ages are available for Holocene deposits in the Chapter House North Cave (Petraglia et al., 2009).

Extensive deposits of tephra from the YTT super-eruption have been noted in the Jurreru Valley, $13 \mathrm{~km}$ south-southwest of Billa Surgam, as well as a number of other Indian localities

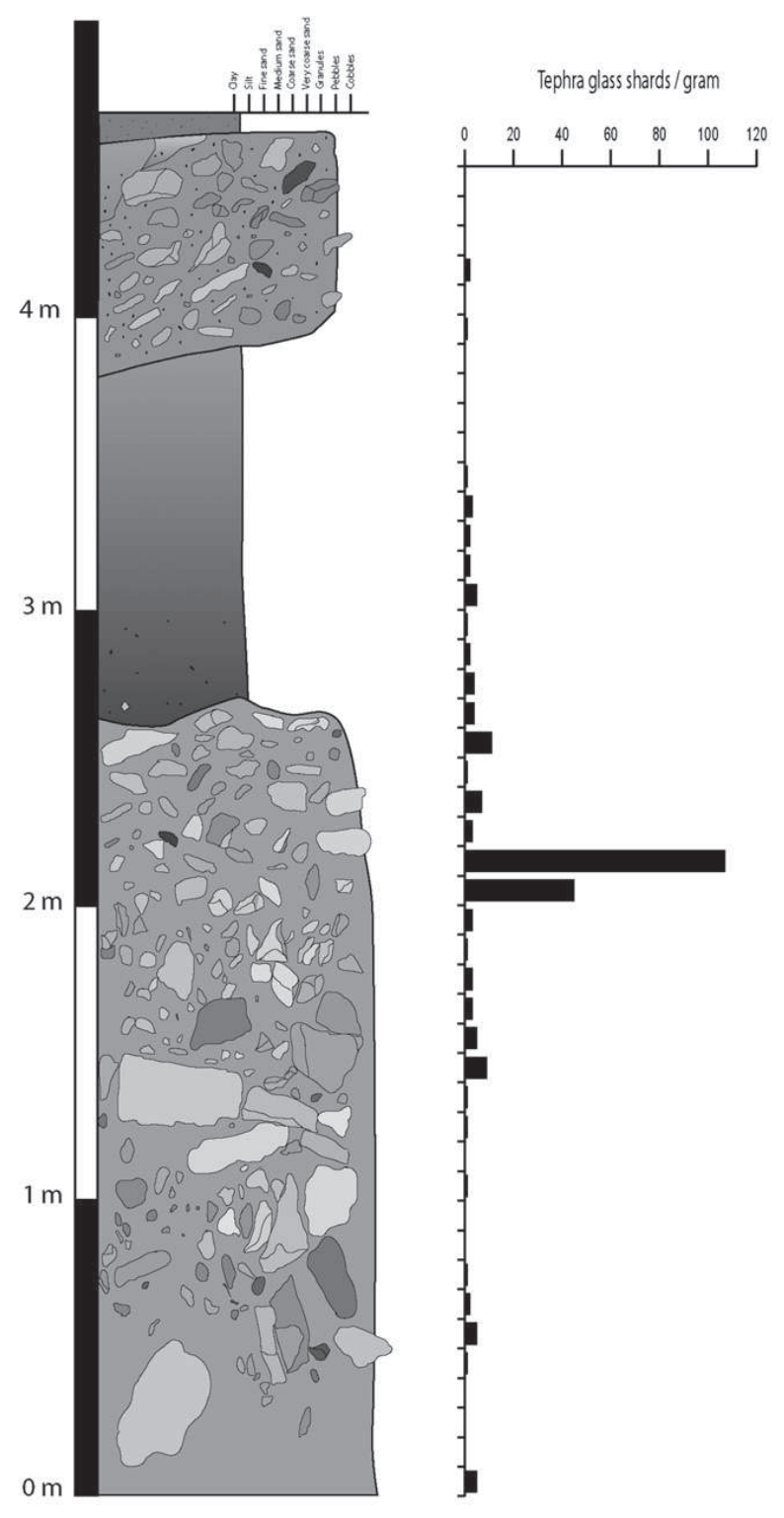

(Jones, 2007; Petraglia et al., 2007; Haslam et al., 2010a). As the Billa Surgam caves preserve a Pleistocene sequence of several metres depth, including fauna such as Rhinoceros that are no longer present in the region (Lydekker, 1886), we anticipated that the cave stratigraphy might contain a YTT horizon. Cryptotephra analysis was attempted because a macroscopically visible tephra layer has not been identified in any cave in the Billa Surgam system during the past 160 years.

\subsection{Charnel House Cave}

The site chosen for cryptotephra investigation was Charnel House Cave (CHC). This cave was excavated to bedrock across most of its extent in the 1880s (Foote, 1884a), leaving only a block of original sediment standing at the entrance (Haslam et al., 2010b). The

Notes

Disturbed silty layer containing charcoal and pottery

Pebble to boulder grade conglomerate, poorly sorted, well imbricated, dipping away from cave wall. Boulders are predominantly angular limestone whereas pebbles are a mixture of angular limestone and more rounded other lithologies indicating moderate external sourcing of clasts. Intersecting ashy silt pit fills near top of unit

Orange brown clay rich silt (cave earth)

Coarse angular boulder rubble with beige brown cave earth matrix, clast supported, boulders dominated by weathered limestone roof rock

Zone of angular limestone cobbles strongly clast supported

Prominent concentration of large angular limestone boulders with fitted fabric.

Base not seen

Fig. 2. Sedimentary log and lithological descriptions for the sampled Charnel House Cave sediments, with cryptotephra shard concentrations (s/g) plotted for each $10 \mathrm{~cm}$ depth sample. 
remaining sedimentary sequence (Fig. 2) consists of over $4.5 \mathrm{~m}$ of clast-supported, weathered, angular to sub-rounded limestone cobble and boulder rubble in a yellowish-red to brown silty matrix, overlain by $\sim 1.3 \mathrm{~m}$ of relatively undifferentiated yellowish-red silts, in turn overlain by $0.8-0.9 \mathrm{~m}$ of poorly sorted pebble-to-boulder grade conglomerate with likely mixed sediments at the very top. The interface between each of the cobble beds and the intervening silt layer is reasonably distinct and sharp, representing two dramatic changes in the sediment depositional regime. The limestone clasts are primarily derived from significant roof-fall events, and as the roof of the site is tens of metres high there are a number of naturallyfractured limestone pieces throughout the upper and lower rubble-beds. While this makes identification of cultural products difficult, there are presently no indisputably manufactured lithic items recovered from Charnel House Cave. A large number of microfaunal remains have been collected from the CHC sequence, along with a lesser number of macrofaunal skeletal elements, and these are currently being analysed for evidence of human processing.

\section{Cryptotephra analysis methods}

\subsection{Sampling and laboratory processing}

A total of 46 sediment samples collected at $10 \mathrm{~cm}$ intervals from the preserved CHC sediments (Fig. 2) were sub-sampled for cryptotephra investigations. These include 25 samples from the lower, weathered limestone rubble layer, 14 from within the silts, and 7 from the upper rubble layer. The samples were collected following cleaning of the exposed section, and sampling was conducted from the base of the sequence upwards to minimise any contamination. Cryptotephra extraction methods followed Blockley et al. (2005), with all sub-samples weighed to allow quantification of the number of shards per gram $(\mathrm{s} / \mathrm{g})$ of sediment.

\subsection{Compositional analysis}

Where tephra was located, glass shards were picked manually from the extracted sediment. These were then mounted in epoxy resin, ground and polished for compositional analysis. Electron probe microanalysis, using wavelength-dispersive spectroscopy (WDS-EPMA), was carried out on the JEOL JXA-8600 at the Research Laboratory for Archaeology and the History of Art, University of Oxford. Eleven major elements were analysed ( $\mathrm{Si}$, Ti, $\mathrm{Al}, \mathrm{Fe}, \mathrm{Mn}, \mathrm{Mg}, \mathrm{Ca}, \mathrm{Na}, \mathrm{K}, \mathrm{P}$ and $\mathrm{Cl}$ ) with an accelerating voltage of $15 \mathrm{kV}$, a $6 \mathrm{nA}$ beam current and $10 \mu \mathrm{m}$ defocused beam. Secondary standard glass StHs6/80-G from the MPI-DING fused volcanic glass sample set (Jochum et al., 2006) was used to check the instrument calibration and monitor for drift during the analysis session.

\section{Results}

\subsection{Tephra glass shard concentrations}

A distinct peak in tephra glass shard concentrations, of $140 \mathrm{~s} / \mathrm{g}$, was observed at $2.20 \mathrm{~m}$ (sample CHC_T2.20), $\sim 0.40 \mathrm{~m}$ below the transition from the coarse rubble-beds to the fine-grained claysilts (Fig. 2). As the samples were not contiguous, the exact first appearance of the tephra layer cannot be established, however the highest concentrations appear to occur above $2.10 \mathrm{~m}$ and below $2.30 \mathrm{~m}$, and this $<20 \mathrm{~cm}$ range is at a comparable resolution to the archaeological stratigraphy. The tephra in CHC_T2.20 appear colourless and are a mix of curvilinear plate-like shards and shards with elongate fluting. Shard sizes range from 50 to $150 \mu \mathrm{m}$ (longest axis length). Tephra shard counts of $<10 \mathrm{~s} / \mathrm{g}$, found in samples throughout the excavated section are not considered to represent other tephra fall events. These trace deposits are instead explained by a combination of biogenic and/ or geologic reworking of small tephra particles within the dry and unconsolidated sediments (as observed in other terrestrial sedimentary contexts, c.f. Lowe, 2011) and limited aeolian input of YTT material transported from exposures in the surrounding landscape, which could have taken place over the past several millennia.

\subsection{WDS-EPMA}

Results of WDS-EPMA are presented in Table 1 alongside secondary standard glass analyses. Five analyses were achieved on CHC_T2.20 and these show a homogeneous rhyolitic composition. Fig. 3 compares the major element composition of CHC_T2.20 to a sample from the visible YTT deposits in the Jwalapuram Middle Palaeolithic site in the Jurreru river valley (Smith et al., in press) and to the composition of the proximal YTT, sampled in Sumatra, by Westgate et al. (1998). A good match is apparent to both reference datasets. There have been two other eruptions of the Toba caldera with similar glass compositions: the $\sim 0.79$ Ma Older Toba Tuff and the $\sim 0.5$ Ma Middle Toba Tuff (Smith et al., in press). However, tephra of such antiquity would not be expected in Late Pleistocene contexts and to date these have not been found on the Indian continent. The compositional match (Fig. 3) therefore confirms that CHC_T2.20 is a deposit of the $\sim 74$ ka YTT.

Table 1

Results of WDS-EPMA of tephra glass shards $(n=5)$ from sample CC_T2.20 from Charnel House Cave, along with summary data from associated StHs6/80-G secondary standard glass analyses (in grey shade). Summary data for the YTT from the Jwalapuram archaeological site (Smith et al., in press) is also included.

\begin{tabular}{|c|c|c|c|c|c|c|c|c|c|c|c|}
\hline & $\mathrm{SiO}_{2} \mathrm{wt} \%$ & $\mathrm{TiO}_{2} \mathrm{wt} \%$ & $\mathrm{Al}_{2} \mathrm{O}_{3} \mathrm{wt} \%$ & $\mathrm{FeO} w \mathrm{t} \%$ & MnO wt $\%$ & MgO wt\% & $\mathrm{CaO} w \mathrm{w} \%$ & $\mathrm{Na}_{2} \mathrm{O} w t \%$ & $\mathrm{~K}_{2} \mathrm{O}$ wt $\%$ & $\mathrm{P}_{2} \mathrm{O}_{5} \mathrm{wt} \%$ & Total \\
\hline \multicolumn{12}{|l|}{ Charnel House Cave } \\
\hline CHC_T2.20/1 & 73.95 & 0.05 & 12.09 & 0.96 & 0.10 & 0.06 & 0.74 & 3.17 & 5.09 & 0.00 & 96.2 \\
\hline CHC_T2.20/2 & 74.77 & 0.07 & 12.04 & 0.86 & 0.12 & 0.04 & 0.64 & 3.21 & 5.01 & 0.02 & 96.8 \\
\hline CHC_T2.20/3 & 74.97 & 0.04 & 12.02 & 0.86 & 0.12 & 0.06 & 0.80 & 3.00 & 4.85 & 0.04 & 96.8 \\
\hline CHC_T2.20/4 & 74.17 & 0.03 & 12.19 & 0.84 & 0.07 & 0.04 & 0.79 & 2.91 & 4.98 & 0.02 & 96.0 \\
\hline CHC_T2.20/5 & 74.72 & 0.05 & 12.04 & 0.78 & 0.05 & 0.06 & 0.65 & 3.24 & 4.82 & 0.03 & 96.4 \\
\hline \multicolumn{12}{|c|}{ StHs6/80-G secondary standard summary data } \\
\hline Average $(n=3)$ & 63.9 & 0.72 & 17.9 & 4.35 & 0.05 & 2.00 & 5.25 & 4.46 & 1.30 & 0.14 & \\
\hline $2 \sigma$ & 0.10 & 0.12 & 0.28 & 0.34 & 0.09 & 0.08 & 0.11 & 0.07 & 0.09 & 0.01 & \\
\hline \multicolumn{12}{|c|}{ Jwalapuram YTT summary data } \\
\hline Average $(n=148)$ & 77.36 & 0.05 & 12.46 & 0.87 & 0.07 & 0.06 & 0.75 & 3.25 & 4.96 & 0.03 & 99.9 \\
\hline $2 \sigma$ & 0.56 & 0.05 & 0.39 & 0.18 & 0.09 & 0.21 & 0.15 & 0.33 & 0.32 & 0.03 & \\
\hline
\end{tabular}



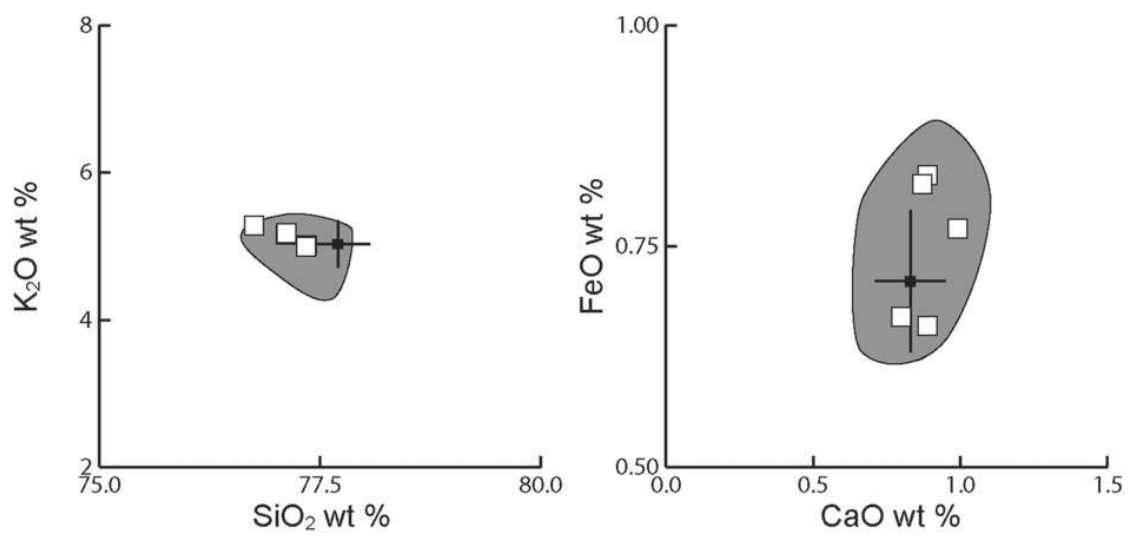

$\square \mathrm{CHC}_{-} \mathrm{T} 2.20 \quad \longrightarrow$ YTT (proximal)

Fig. 3. Correlation of major element glass chemistry of CC_T2.20 with tephra glass from Jwalapuram archaeological site in the Jurreru Valley, India, and with the proximal YTT glass from Sumatra (error bars represent the two standard deviation uncertainty range around the published mean from Westgate et al., 1998).

\section{Implications}

\subsection{YTT in Charnel House Cave}

The discovery of the YTT as a cryptotephra layer in Charnel House Cave provides an isochronous marker horizon, which allows the faunal record of the site to be directly correlated to other archaeological sites in India that preserve the YTT as a visible layer. The age of the YTT is $\sim 74$ ka BP and this can be imported into the Charnel House Cave sediment sequences, at around $2.20 \mathrm{~m}$ (Fig. 2). This is the first numerical age determination for the site. The position of the YTT indicates that the deposition of the lower rubble layers dates to MIS 5 and continued for a period after the YTT before the abrupt transition to deposition of fine silts occurred.

As noted above, there are no definitive Pleistocene archaeological artefacts recovered to date in the cave. However, initial analysis of faunal material has identified cut-marked nonhuman primate bones (cf. Presbytis) near the base of the exposed lower rubble layer (Miracle, 2010). This finding suggests hominin presence and subsistence behaviour in the Billa Surgam caves prior to the Toba eruption, likely during MIS 5, indicating that further archaeological exploration of the cave system is warranted.

\subsection{Cryptotephra as a tool in archaeology}

This study presents the first published occurrence of a cryptotephra layer detected within the sediments of a Palaeolithic cave. It is also the first application of cryptotephrochronology within South Asia. The successful location and identification of the YTT in the Billa Surgam caves highlights the potential to explore and date more sites in India that are likely to preserve late MIS 5 sediments but do not have macroscopic tephra layers. Such finds would build on the known network of terrestrial and marine sites connected by the presence of the YTT (Acharyya and Basu, 1993), allowing comparison of regional records on a common chronological timescale.

Furthermore, our results suggest that cryptotephra layers may be preserved as discrete event horizons within a more diverse range of sedimentary contexts than have been investigated to date. This includes sheltered sites, such as exogene caves or rockshelters, that may not be directly exposed to tephra fallout, but which frequently contain valuable Palaeolithic archaeological deposits.

\section{Acknowledgements}

CSL is grateful to the Quaternary Research Association for funding this work through the Quaternary Research Fund, and the UK NERC consortium RESET (NE/E015670/1). The Archaeological Survey of India granted permission for the fieldwork. The British Academy, the Leverhulme Trust, the Leakey Foundation, and the McDonald Institute for Archaeological Research supported the fieldwork and analyses. We thank Adam Durant for assistance with sample collection.

\section{References}

Acharyya, S.K., Basu, P.K., 1993. Toba ash on the Indian subcontinent and its implications for correlation of Late Pleistocene alluvium. Quaternary Research 40, $10-19$.

Ambrose, S.H., 1998. Late Pleistocene human populations bottlenecks, volcanic winter, and differentiation of modern humans. Journal of Human Evolution 34, $623-651$.

Blockley, S., Pyne-O'Donnell, S., Lowe, J., Matthews, I., Stone, A., Pollard, A.M., Turney, C., Molyneux, E., 2005. A new and less destructive laboratory procedure for the physical separation of distal glass tephra shards from sediments. Quaternary Science Reviews 24, 1952-1960.

Buhring, C., Sarnthein, M., Leg 184 Shipboard Scientific Party, 2000. Toba ash layers in the South China Sea: evidence of contrasting wind directions during eruption ca. 74 ka. Geology 28, 275-278.

Cammiade, L.A., 1927. Prehistoric man in India and the Kurnool Bone Caves: a neglected field of inquiry. Man in India 7, 1-12.

Duff, M.E.G., 1883a. Letter to Thomas H. Huxley, 8 January 1883. Imperial College London Thomas Henry Huxley Collection, Series 1d, Inventory ID 15.13.

Duff, M.E.G., 1883b. Letter to Thomas H. Huxley, 30 December 1883. Imperial College London Thomas Henry Huxley Collection, Series 1d, Inventory ID 15.15.

Duff, M.E.G., 1884. Letter to Thomas H. Huxley, 21 January 1884. Imperial College London Thomas Henry Huxley Collection, Series 1d, Inventory ID 15.18.

Dugmore, A., Larsen, G., Newton, A., 1995. Seven tephra isochrones in Scotland. Holocene 5, 257-266.

Foote, R.B., 1884a. Mr H.B. Foote's work at the Billa Surgam caves. Records of the Geological Survey of India 17, 200-208.

Foote, R.B., 1884b. Rough notes on Billa Surgam and other caves in the Kurnool District. Records of the Geological Survey of India 17, 27-34.

Foote, R.B., 1885. Notes on the results of Mr H.B. Foote's further excavations in the Billa Surgam caves. Records of the Geological Survey of India 18, 227-235.

Haslam, M., Petraglia, M., 2010. Comment on 'Environmental impact of the 73 ka Toba super-eruption in South Asia', by M. Williams et al. [Palaeogeography, Palaeoclimatology, Palaeoecology 284 (2009) 295-314]. Palaeogeography, Palaeoclimatology, Palaeoecology 296, 199-203.

Haslam, M., Clarkson, C., Petraglia, M., Korisettar, R., Bora, J., Boivin, N., Ditchfield, P., Jones, S., Mackay, A., 2010a. Indian lithic technology prior to the 74,000 BP Toba super-eruption: searching for an early modern human signature. In: Boyle, K., Gamble, C., Bar-Yosef, O. (Eds.), The Upper Palaeolithic Revolution in Global Perspective: Essays in Honour of Paul Mellars. McDonald Institute for Archaeological Research, Cambridge, pp. 73-84. 
Haslam, M., Korisettar, R., Petraglia, M., Smith, T., Shipton, C., Ditchfield, P., 2010b. In Foote's steps: the history, significance and recent archaeological investigation of the Billa Surgam caves in southern India. South Asian Studies 26, 1-19.

Jochum, K., Stoll, B., Herwig, K., Willbold, M., Hofmann, A., Amini, M., Arbug, S., Abouchami, W., Hellebrand, E., Mocek, B., Raczek, I., Stracke, A., Alard, O., Bouman, C., Becker, S., Ducking, M., Bratz, H., Klemd, R., de Bruin, D., Canil, D., Cornell, D., de Hoog, C., Dalpe, C., Danyushevsky, L., Eisenhauer, A., Gao, Y. Snow, J., Goschopf, N., Gunther, D., Latkoczy, C., Guilong, M., Hauri, E., Hofer, H., Lahaye, Y., Horz, K., Jacob, D., Kassemann, S., Kent, A., Ludwig, W., Sun, W., Tiepolo, M., Vannucci, R., Vennemann, T., Wayne, D., Woodhead, J., 2006. MPI-DING reference glasses for in situ microanalysis: new reference values for element concentrations and isotope ratios. Geochemistry Geophysics Geosystems 7. Q02008.

Jones, S., 2007. The Toba supervolcanic eruption: tephra-fall deposits in India and palaeoanthropological implications. In: Petraglia, M., Allchin, B. (Eds.), The Evolution and History of Human Populations in South Asia. Springer, New York, pp. $173-200$.

Lane, C.S., Blockley, S., Lotter, A., Finsinger, W., Filippi, M., Matthews, I. A regional tephrostratigraphic framework for central and southern European climate archives during the Last Glacial to Interglacial transition: comparisons north and south of the Alps. Quaternary Science Reviews, in press. doi:10.1016/j. quascirev.2010.10.015.

Lowe, D.J., 2011. Tephrochronology and its application: a review. Quaternary Geochronology 6, 107-153.

Lowe, J., Turney, C., 1997. Vedde ash layer discovered in a small lake basin on the Scottish mainland. Journal of the Geological Society 154, 605-612.

Lydekker, R., 1886. The fauna of the Kurnool Caves. Palaeontologica Indica, Series X $4,23-58$.

Margari, V., Pyle, D.M., Bryant, C., Gibbard, P.L., 2007. Mediterranean tephra stratigraphy revisited: results from a long terrestrial sequence on Lesvos Island, Greece. Journal of Volcanology and Geothermal Research 163, 34-54.

Miracle, P., 2010. Site use and human subsistence post-Toba in the Kurnool District, India. In: Special Leverhulme Conference, The Toba Super-Eruption: A Critica Moment in Human Evolution? Centre for Asian Archaeology, Art \& Culture, Oxford, 20-21st February 2010. http://toba.arch.ox.ac.uk/confabs.pdf.

Murty, M.L.K., 1974. A Late Pleistocene cave site in southern India. Proceedings of the American Philosophical Society 118, 196-230.

Murty, M.L.K., Reddy, K.T., 1975. The significance of lithic finds in the cave areas of Kurnool, India. Asian Perspectives 18, 214-226.

Newbold, T.J., 1844. Note on the osseous breccia and deposit in the caves of Billa Surgam, Lat. $15^{\circ} 25^{\prime}$, Long. $78^{\circ} 15^{\prime}$, southern India. Journal of the Asiatic Society of Bengal 13, 610-611.

Ninkovich, D., Shackleton, N.J., Abdel-Monem, A.A., Obradovich, J.D., Izett, G., 1978. $\mathrm{K}-\mathrm{Ar}$ age of the Late Pleistocene eruption of Toba, north Sumatra. Nature 276 574-577.

Oppenheimer, C., 2002. Limited global change due to the largest known Quaternary eruption, Toba 74 kyr BP? Quaternary Science Reviews 21, 1593-1609.

Petraglia, M., Korisettar, R., Boivin, N., Clarkson, C., Ditchfield, P., Jones, S., Koshy, J., Lahr, M.M., Oppenheimer, C., Pyle, D., Roberts, R., Schwenninger, J.-L., Arnold, L.,
White, K., 2007. Middle Palaeolithic assemblages from the Indian subcontinent before and after the Toba super-eruption. Science 317, 114-116.

Petraglia, M., Korisettar, R., Kasturi Bai, M., Boivin, N.B.J., Clarkson, C., Cunningham, K. Ditchfield, P. Fuller, D., Hampson, J., Haslam, M. Jones, S., Koshy, J., Miracle, P., Oppenheimer, C., Roberts, R., White, K., 2009. Human occupation, adaptation and behavioral change in the Pleistocene and Holocene of south India: recent investigations in the Kurnool District, Andhra Pradesh. Eurasian Prehistory 6, 119-166.

Prasad, K.N., 1996. Pleistocene cave fauna from peninsular India. Journal of Caves and Karst Studies 58, 30-34.

Rampino, M., Self, S., 1992. Volcanic winter and accelerated glaciation following the Toba super-eruption. Nature 359, 50-52.

Reddy, K.T., 1977. Billa Surgam: an Upper Palaeolithic cave site in south India. Asian Perspectives 20, 206-227.

Robock, A., Ammann, C., Oman, L., Shindell, D., Levis, S., Stenchikov, G., 2009. Did the Toba volcanic eruption of $\sim 74$ ka B.P. produce widespread glaciation? Journal of Geophysical Research 114, D10107.

Rose, W.I., Chesner, C.A., 1987. Dispersal of ash in the great Toba eruption, 75 ka. Geology 15, 913-917.

Schulz, H., Emeis, K.-C., Erlenkeuser, H., von Rad, U., Rolf, C., 2002. The Toba volcanic event and interstadial/stadial climates at the marine isotopic stage 5 to 4 transition in the northern Indian Ocean. Quaternary Research 57, 22-31.

Smith, V.C., Pearce, N.J.G., Matthews, N.E., Westgate, J.A., Petraglia, M.D., Michael Haslam, M., Lane, C., Korisettar, R., Pal, J.N. Geochemical fingerprinting the widespread Toba tephra using biotite compositions. Quaternary International, in press.

Timmreck, C., Graf, H.-F., Lorenz, S.J., Niemeier, U., Zanchettin, D., Matei, D., Jungclaus, J.H., Crowley, T.J., 2010. Aerosol size confines climate response to volcanic super-eruptions. Geophysical Research Letters 37, 24. L24705.

Turney, C., Lowe, J., Davies, S., Hall, V., Lowe, D., Wastegard, S., Hoek, W., Alloway, B.V., 2004. Tephrochronology of last termination sequences in Europe: a protocol for improved analytical precision and robust correlation procedures (a joint SCOTAVINTIMATE proposal). Journal of Quaternary Science 19, 111-120.

Wastegård, S., Turney, C., Lowe, J., Roberts, S., 2000. New discoveries of the Vedde ash in southern Sweden and Scotland. Boreas 29, 72-78.

Westgate, J., Shane, P., Pearce, N., Perkins, W., Korisettar, R., Chesner, C.A., Williams, M., Acharyya, S.K., 1998. All Toba tephra occurrences across peninsular India belong to the 75,000 yr B.P. eruption. Quaternary Research 50, 107-112.

Williams, M., Ambrose, S.H., van der Kaars, S., Ruehlemann, C., Chattopadhyaya, U.C., Pal, J.N., Chauhan, P., 2009. Environmental impact of the 73 ka Toba supereruption in South Asia. Palaeogeography, Palaeoclimatology, Palaeoecology 284, 295-314.

Williams, M., Ambrose, S.H., van der Kaars, S., Ruehlemann, C., Chattopadhyaya, U.C., Pal, J.N., Chauhan, P., 2010. Reply to the comment on "Environmental impact of the 73 ka Toba super-eruption in South Asia" by M. A. J. Williams, S. H. Ambrose, S. van der Kaars, C. Ruehlemann, U. Chattopadhyaya, J. Pal, P. R. Chauhan [Palaeogeography, Palaeoclimatology, Palaeoecology 284 (2009) 295-314]. Palaeogeography, Palaeoclimatology, Palaeoecology 296, 204-211. 